INTERNATIONAL JOURNAL OF CURRENT RESEARCH IN CHEMISTRY AND PHARMACEUTICAL SCIENCES

(p-ISSN: 2348-5213: e-ISSN: 2348-5221)

www.ijcrcps.com

DOI: 10.22192/ijcrcps

Coden: IJCROO(USA)

Volume 8, Issue 5 - 2021

Research Article

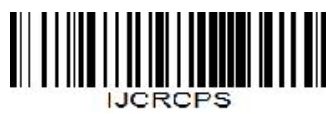

DOI: http://dx.doi.org/10.22192/ijcrcps.2021.08.05.004

\title{
Effect of Solvents on Spectrophotometric Analysis of Carbocisteine by Forming Complex with Ninhydrin
}

\author{
Abdul Aziz Ramadan ${ }^{1 *}$, Hasna Mandil ${ }^{2}$, Ali Marei ${ }^{3}$ \\ Department of Chemistry, Faculty of Science, University of Aleppo, Syria. \\ *11E-mail: dramadan@ scs-net.org or dramadan1946@gmail.com; \\ 2 E-mail: promandi1955@gmail.com \\ ${ }^{3}$ E-mail: alooosh.7.8.93@gmail.com
}

\begin{abstract}
Effect of solvents (methanol, ethanol, isopropanol and acetonitrile) on direct spectrophotometric analysis of carbocisteine in bulk and pharmaceutical formulations using complex formed with ninhydrin (NN) was studied. The method is based on reaction of ninhydrin with primary amino groups to form the purple dye. Various parameters ( $\mathrm{pH}$, heating time, temperature, concentration $\mathrm{NN}$, etc.) affecting the carbocisteine determination were examined. The absorption spectra of this complex occur at wavelengths from 568 to $572 \mathrm{~nm}$ (pH 9.6, heating time $15 \mathrm{~min}$, temperature $90^{\circ} \mathrm{C}$ ). The absorbance's were proportional to the concentration of carbocisteine at the range 1.00 to $100.00 \mu \mathrm{M}\left(0.1792\right.$ to 17.919 g.mL $\left.{ }^{-1}\right)$ for above solvents in present $2.5 \times 10^{-2} \mathrm{M}$ of $\mathrm{NN}$ (which has been dissolved with used solvents). The method was validated for linearity, precision and accuracy, repeatability and robustness. The method was successfully applied for determination of carbocisteine in pure and pharmaceutical formulations samples with relative standard deviations did not exceed $3.2 \%$ for the concentrations of carbocisteine $\left(0.1792 \mathrm{~g} . \mathrm{mL}^{-1}\right)$ in methanol as example.
\end{abstract}

Keywords: Solvents, Carbocisteine, Spectrophotometric method, Ninhydrin. 


\section{Introduction}

Carbocisteine (S-carboxymethyl-L-cysteine) is mucolytic drug used for treatment of disorders of the respiratory tract associated with excessive mucus see scheme 1. Carbocisteine is an odorless white crystalline powder that has a molecular formula of $\mathrm{C}_{5} \mathrm{H}_{9} \mathrm{NO}_{4} \mathrm{~S}$ and a molecular weight of $179.19 \mathrm{~g}$. It is very slightly soluble in water and practically insoluble in ethanol $95 \%$. It dissolves in dilute hydrochloric acid or in sodium hydroxide $[1,2]$.

Scheme 1: Chemical structure of carbocisteine

Ninhydrin (2,2-dihydroxyindane-1,3-dione) is a chemical used to detect ammonia or primary and secondary amines. When reacting with these free amines, a deep blue or purple color known as Rahman's purple is produced. Ninhydrin is most commonly used to detect fingerprints, as the terminal amines of lysine residues in peptides and proteins sloughed off in fingerprints react with ninhydrin. It is a white solid that has a molecular formula of $\mathrm{C}_{9} \mathrm{H}_{6} \mathrm{O}_{4}$ and a molecular weight of $178.14 \mathrm{~g}$. It is soluble in ethanol and acetone at room temperature. Ninhydrin can be considered as the hydrate of indane-1,2,3-trione [1-3], see scheme 2 .<smiles>O=C1c2ccccc2C(=O)C1(O)O</smiles>

Scheme 2: Chemical structure ninhydrin (NN).

Previous research that identified carbocisteine in plasma and bulk drugs which includes fluorimetric method [4,5], in its pure form and in pharmaceutical preparations was identified according to different methods including spectrophotometry [5-12], reversed phase high pressure liquid chromatography (RP-HPLC) $[13,14]$ and high-performance thin-layer chromatography (HPTLC) [15].
In the present work, effect of solvents (methanol, ethanol, isopropanol and acetonitrile) on direct spectrophotometric determination of carbocisteine in pure form and pharmaceutical formulations using ninhydrin (NN) was developed. The method is based on reaction of ninhydrin with primary amino groups to form the purple dye. 


\section{Materials and Methods}

\section{Instruments and apparatus}

Spectrophotometric measurements were made in $\mathrm{T}^{+} 0^{+}$UV-VIS with $1.0 \mathrm{~cm}$ quartz cells. The diluter pipette model DIP-1 (Shimadzu), having 100 L sample syringe and five continuously adjustable pipettes covering a volume range from 10 to 5000 L (model Piptman P, GILSON). SARTORIUS TE64 $(0.01 \mathrm{mg})$ electronic balance was used for weighing.

\section{Reagents}

Carbocisteine $(99.5 \%)$ was supplied by Grand Pharma (China) Co., Ltd. (Wuhan Grand Hoyo Co., Ltd.). Ninhydrin reagent is $99 \%$ of analytical grade from Surechem Products Ltd (England). All solvents and reagents were analytical grade chemicals from Merck.

\section{A stock standard solution of carbocisteine $\left(1 \times 10^{-3} \mathrm{~mol}^{-L^{-1}}\right)$}

Dissolving $18.01 \mathrm{mg}$ of carbocisteine with $20 \mathrm{~mL}$ of $0.10 \mathrm{M} \mathrm{NaOH}$ after that adjusted value $\mathrm{pH} 9.6$ with $0.10 \mathrm{M}$ HCL. Then the volume was transferred to a $100 \mathrm{~mL}$ volumetric flask and diluting to mark by distilled water $\left(1 \times 10^{-3}\right.$ mol. $\left.L^{-1}\right)$.

Stock standard solution of ninhydrin $5 \times 10^{-2}$ mol. $\mathbf{L}^{-1}$

We weigh $224.92 \mathrm{mg}$ of ninhydrin $(99 \%)$ and dissolve it with $10 \mathrm{~mL}$ of used solvent (methanol, ethanol, isopropanol and acetonitrile). Then the volume was transferred to a $25 \mathrm{~mL}$ volumetric flask and diluting to mark by the same solvent $\left(5 \times 10^{-2} \mathrm{~mol} . \mathrm{L}^{-1}\right)$.

\section{Working solutions and general procedure}

The stock solutions were further diluted to obtain working solutions daily just before use in the ranges of carbocisteine: $1.00,2.00,5.00,10.00$, $20.00,40.00,60.00,80.00$ and $100.0 \mu \mathrm{mol} . \mathrm{L}^{-1}$ (0.1792, 0.3584, 0.8960, 1.7919, 3.5838, 7.1676,
$10.7514,14.3352$ and 17.919 g.mL ${ }^{-1}$ ) by dilution of the volumes: $5,10,25,50,100,200,300,400$ and $500 \mu \mathrm{L}$ from stock standard solutions of carbocisteine $\left(1 \times 10^{-3} \mathrm{~mol} . \mathrm{L}^{-1}\right)$ into $5 \mathrm{~mL}$ volumetric flask, then added $2.5 \mathrm{~mL}$ from stock standard solution of ninhydrin $\left(5 \times 10^{-2}\right.$ mol. $\left.\mathrm{L}^{-1}\right)$, $0.4 \mathrm{~mL}$ of $0.10 \mathrm{M} \mathrm{NaOH}$ (adjusted $\mathrm{pH} 9.6$ with $0.10 \mathrm{M} \mathrm{HCl}$ ), diluted to $5 \mathrm{~mL}$ with distilled water and the flask was heated on a water bath at $90^{\circ} \mathrm{C}$ for $15 \mathrm{~min}$. After the flask had been cooled to room temperature, the solution was made up to the mark with studding solvent. The absorbance of the solution was measured against a reagent blank at used $\lambda_{\max }$.

\section{Sample preparation}

Commercial formulations (as capsule) were used for the analysis of carbocisteine. The pharmaceutical formulations subjected to the analytical procedure were:

(1) Mucolar capsule, ELSAAD PHARMACEUTICAL, Aleppo - SYRIA, each capsule contains $375 \mathrm{mg}$ of carbocisteine (Mfg. 10/2019, Exp. 10/2023).

(2) Mucoxil capsule, Al-SHAHBA PHARMACEUTICAL, Aleppo - SYRIA, each capsule contains $375 \mathrm{mg}$ of carbocisteine (Mfg. 9/2017, Exp. 9/2021).

(3) Carbocisteie capsule, Al-YOUSEF PHARMACEUTICAL, Damascus - SYRIA, each capsule contains $375 \mathrm{mg}$ of carbocisteine (Mfg. 10/2017, Exp. 10/2021).

\section{Stock solutions of pharmaceutical formulations}

Contents of 20 capsules of each studied pharmaceutical formulations were weighted accurately and mixed well. An amount of the powder equivalent to the weight of tenth content of capsule of carbocisteine was solved in $40 \mathrm{~mL}$ of $0.10 \mathrm{M} \mathrm{NaOH}$ using ultrasonic for $15 \mathrm{~min}$. After that adjusted $\mathrm{pH} 9.6$ with $0.10 \mathrm{M}$ HCL. Then the volume was transferred to a $100 \mathrm{~mL}$ volumetric flask and diluting to mark by distilled water (37.5 $\mathrm{mg} / 100 \mathrm{~mL}$ or $2.093 \times 10^{-3} \mathrm{M}$ ). 


\section{Working solutions of pharmaceuticals}

These solutions were prepared daily by diluting $100 \mu \mathrm{L}(0.100 \mathrm{~mL})$ from stock solutions of pharmaceutical formulations into $5 \mathrm{~mL}$ volumetric flask, then added $2.5 \mathrm{~mL}$ from suitable stock standard solution of ninhydrin $\left(5 \times 10^{-2}\right.$ mol. $\mathrm{L}^{-1}$ ), $0.4 \mathrm{~mL}$ of $0.10 \mathrm{M} \mathrm{NaOH}$ (adjusted $\mathrm{pH}$ 9.6 with $0.10 \mathrm{M} \mathrm{HCl}$ ) and diluted to $5 \mathrm{~mL}$ with distilled water and the flask was heated on a water bath at $90^{\circ} \mathrm{C}$ for $15 \mathrm{~min}$. After the flask had been cooled to room temperature, the solution was made up to the mark with studding solvent. The absorbance of the solution was measured against a reagent blank at used $\lambda_{\max }$.

\section{Results and Discussion}

\section{Spectrophotometric results}

UV-Vis spectra of carbocisteine(CS), ninhydrin(NN) and the formed complex $[\mathrm{CS}]:[\mathrm{NN}]$ solutions in solvents (acetonitrile, isopropanol, ethanol and methanol with water 1:1) was obtained. CS and NN solutions do not absorb in the range 450-800 $\mathrm{nm}$. [CS]:[NN] complex solutions have maximum absorption at $\lambda_{\max } 568$ $572 \mathrm{~nm}$ ( $\varepsilon$ for the complex was 8827, 11387, 13180 and $13425 \mathrm{~L} \cdot \mathrm{mol}^{-1} \cdot \mathrm{cm}^{-1}$ in mentioned solvents, respectively). See Figure 2 as example in methanol.

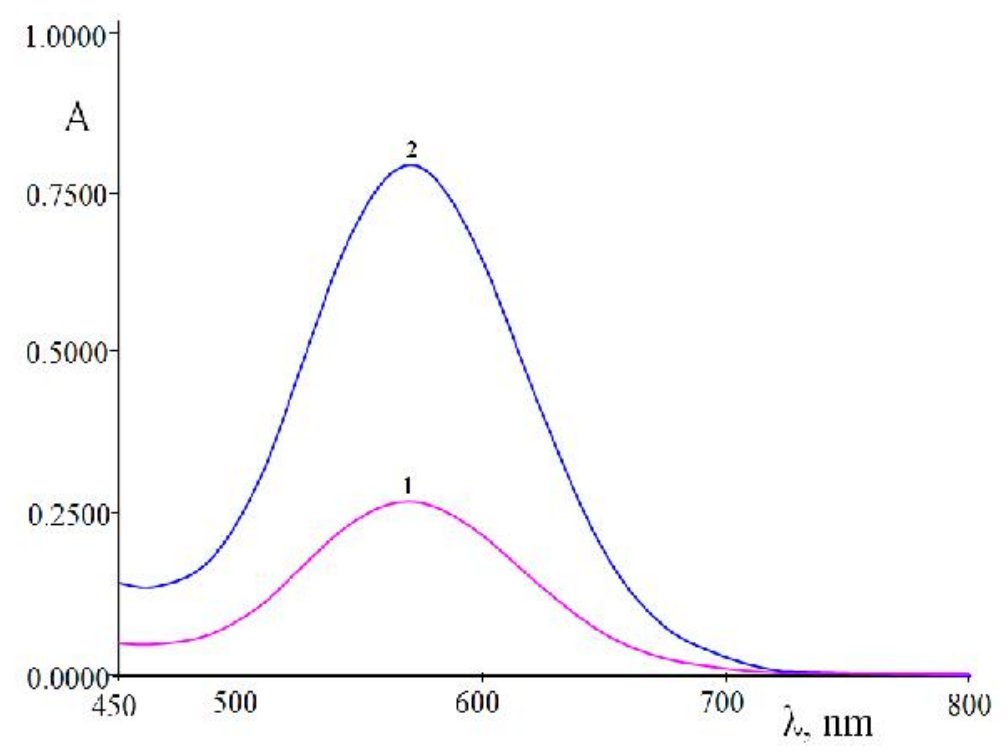

Fig.1. Spectra in methanol-water (1:1) of: 1 - complex $20 \mu \mathrm{mol} . \mathrm{L}^{-1}$ of CS with $2.5 \times 10^{-2}$ mol. $\mathrm{L}^{-1}$ of NN ); 2- complex $60 \mu \mathrm{mol} . \mathrm{L}^{-1}$ of CS with $2.5 \times 10^{-2} \mathrm{~mol} . \mathrm{L}^{-1}$ of NN $)$; Blank is $2.5 \times 10^{-2} \mathrm{~mol} . \mathrm{L}^{-1}$ of $\mathrm{NN} ;(\ell=1 \mathrm{~cm}$. $\mathrm{t}=90^{\circ} \mathrm{C}$ heating time $15 \mathrm{~min}, \mathrm{pH} 9.6$ ).

\section{The effect of pH}

The influence of $\mathrm{pH}$ solutions on spectrum of complex $[\mathrm{CS}]:[\mathrm{NN}]$ in methanol-water (1:1) from $\mathrm{pH}$ (3.0 to12) using $0.4 \mathrm{~mL}$ of $0.10 \mathrm{M} \mathrm{NaOH}(\mathrm{pH}$ adjustment by $0.10 \mathrm{M} \mathrm{HCl}$ ) on absorbance (A) and $\lambda_{\max }$ were studied. The absorbance value increases with increasing $\mathrm{pH}$ value of 3.0 to 5.0, then becomes semi-fixed between $\mathrm{pH} 5.0$ to 8.5 , after that increases until $\mathrm{pH}$ 9.3, then becomes semi-fixed again between $\mathrm{pH} 9.3$ to 10.5 and finally decreases. While $\lambda_{\max }$ semi-fixed at $\mathrm{pH}$ (3.0 to 12 ), see Figure 1. The optimum $\mathrm{pH}$ was found to be 9.6. 


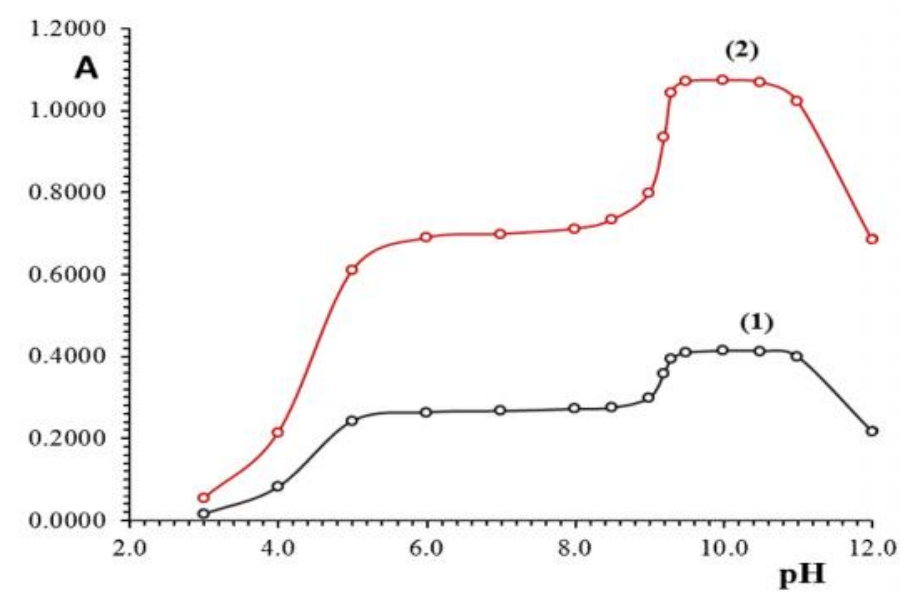

Fig.2: The effect of $\mathrm{pH}$ solutions on spectrum of complex $[\mathrm{CS}]:[\mathrm{NN}]$ in methanol-water $(1: 1)$ : 1- complex $30 \mu \mathrm{mol} . \mathrm{L}^{-1}$ of CS with $2.5 \times 10^{-2} \mathrm{~mol} . \mathrm{L}^{-1}$ of NN ; 2- complex $80 \mu \mathrm{mol} . \mathrm{L}^{-1}$ of CS with $2.5 \times 10^{-2}$ mol. $\mathrm{L}^{-1}$ of $\mathrm{NN}\left(\ell=1 \mathrm{~cm} . \mathrm{t}=90^{\circ} \mathrm{C}\right.$ heating time $\left.15 \mathrm{~min}\right)$

\section{The effect of solvent}

The effect of ratio solvents -water on absorbance of formed complex [CS]:[NN]. The study revealed that the color development remained stable in $50 \%(\mathrm{~V} / \mathrm{V})$ methanol - water, see Figure 3 as example.

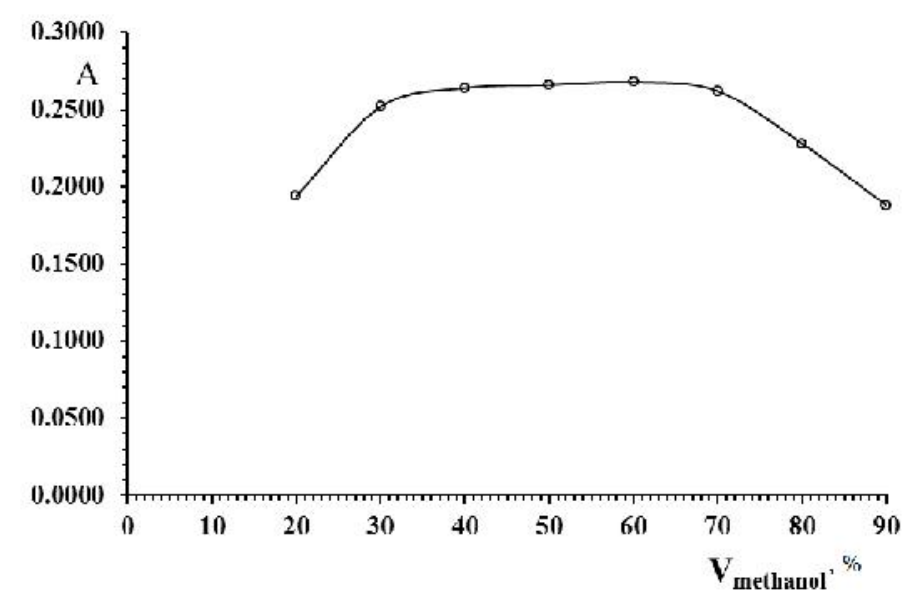

Fig.3: The effect of ratio methanol - water on absorbance of formed complex $[\mathrm{CS}]:[\mathrm{NN}]\left(\mathrm{C}_{\mathrm{NN}} 2.5 \times 10^{-2} \mathrm{M}\right.$, $\mathrm{C}_{\mathrm{CS}} 20 \mu \mathrm{M}$, Blank is methanol - water, $\ell=1 \mathrm{~cm}$ ).

\section{Effect of temperature and heating time}

The effect of temperature and heating time on the complex $[\mathrm{CS}]:[\mathrm{NN}]$ formation were studied with in the temperature range $15-95^{\circ} \mathrm{C}$ and the heating time range 5-20 $\mathrm{min}$. The reaction mixture was heated on a water bath at $90 \pm 2{ }^{\circ} \mathrm{C}$. A colored product was obtained and the color intensity reached its maximum value after $15 \mathrm{~min}$ of heating. After reaching the ambient temperature, the reaction mixture was transferred to a $5 \mathrm{~mL}$ volumetric flask and diluted to the mark with used solvents. Hence, the absorbance was measured after $15 \mathrm{~min}$ of heating. The results are shown in Figures $4 \& 5$. 


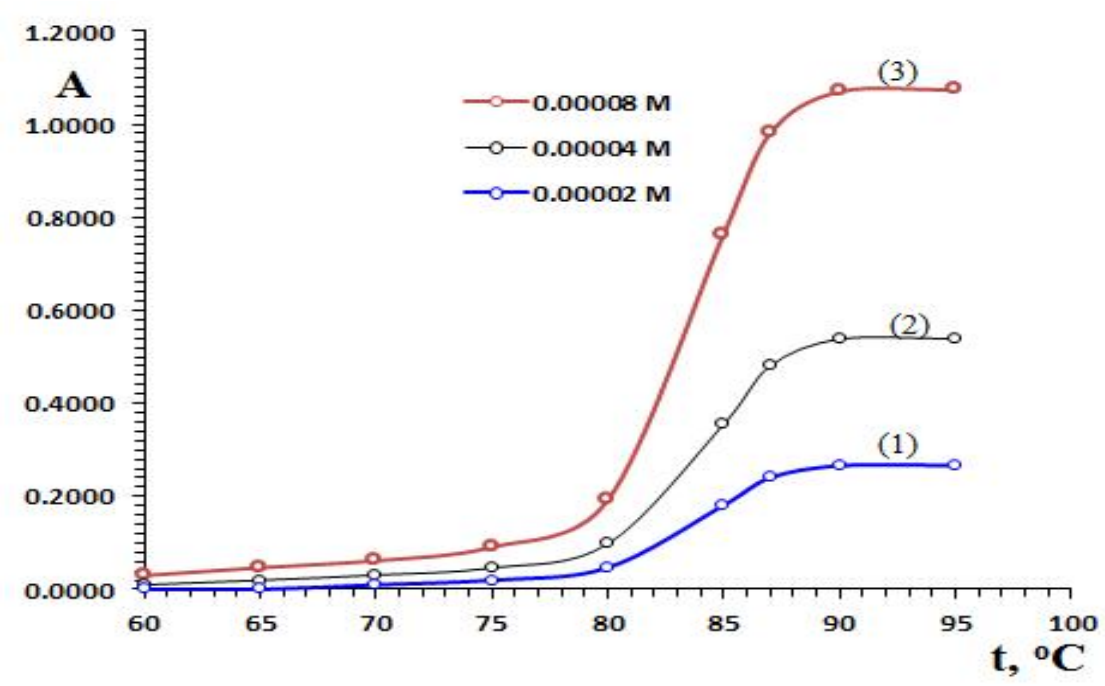

Fig.4: Effect of temperature on color development for the formation complex [CS]:[NN],

$\mathrm{C}_{\mathrm{CS}}:$ 1- $20 \mu \mathrm{M}, 2-40 \mu \mathrm{M}, 3-80 \mu \mathrm{M}$.

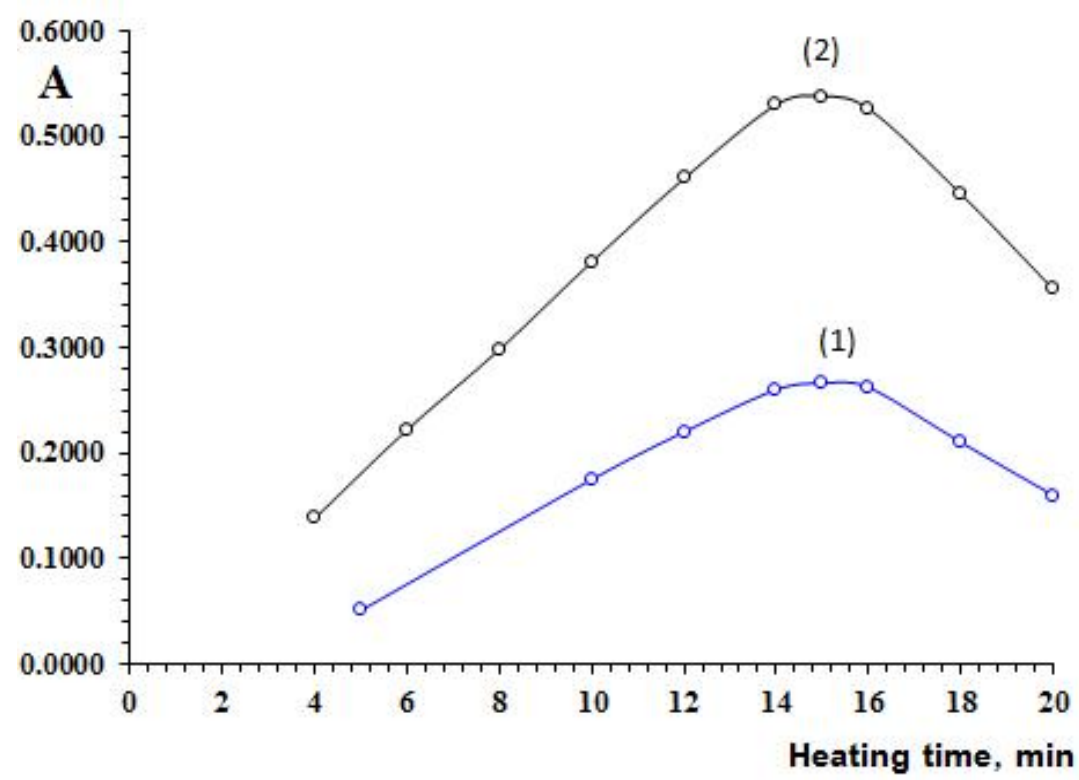

Fig.5: Effect of heating time on color development for the complex [CS]:[NN] formation, where

$\mathrm{C}_{\text {CS: }}$ 1- $20 \mu \mathrm{M}, 2-40 \mu \mathrm{M}$.

\section{Effect of ninhydrin concentration}

To $0.3 \mathrm{~mL}$ of $0.001 \mathrm{M}$ carbocisteine solution, 0.4 $\mathrm{mL}$ of $0.10 \mathrm{M} \mathrm{NaOH}$ (adjusted $\mathrm{pH} 9.6$ with $0.10 \mathrm{M} \mathrm{HCl})$, different volumes $(0.5-4.8 \mathrm{~mL})$ of $0.05 \mathrm{M}$ ninhydrin were added, diluted to $5 \mathrm{~mL}$ with methanol-water (1:1). The reaction mixtures were heated for $15 \mathrm{~min}$ on a water bath at (C) 2021, IJCRCPS. All Rights Reserved
$90 \pm 2{ }^{\circ} \mathrm{C}$. The colored product was diluted to 5 $\mathrm{mL}$ with methanol after heated and the absorbance was measured against a reagent blank at $\lambda_{\max }$. The results showed that the highest absorbance was obtained with $2.5 \mathrm{~mL}$ of $0.05 \mathrm{M}$ ninhydrin solution that remained unaffected with higher amounts (Figure 6). 
The effect of $\mathrm{NN}$ concentration on formation complex [CS]:[NN] was investigated. It was observed that the absorbance of the formed complex increased coinciding with increasing the ratio of $[\mathrm{CS}]:[\mathrm{NN}]$ until the ratio $(1: 250)$, then it becomes almost fixed.

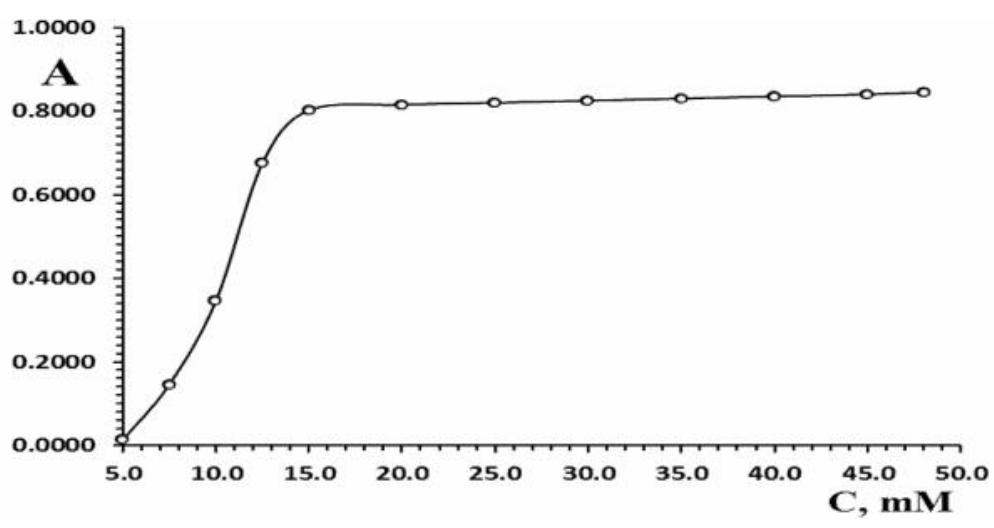

Fig.6: Effect of reagent concentration (ninhydrin) on color development for the formation complex [CS]:[NN], (Carbocisteine $60 \mu \mathrm{M})$.

\section{Mechanism of reaction}

Carbocisteine (CS) reacts with ninhydrin reagent in $0.10 \mathrm{M} \mathrm{NaOH}$ at $\mathrm{pH} 9.6$ ( $\mathrm{pH}$ adjustment by $0.10 \mathrm{M} \mathrm{HCl}$ ) medium via oxidative deamination of the primary amino group followed by the condensation of the reduced ninhydrin to form the colored reaction product Ruhemenn's purple
[16] at $\lambda_{\max }$ (scheme 1). To optimize the reaction conditions, a number of parameters such as heating time, reagent concentration, temperature, $\mathrm{pH}$, stability of color and solvent have investigated. Varying one variable and observing its effect on the absorbance of the colored product established the optimum reaction conditions.

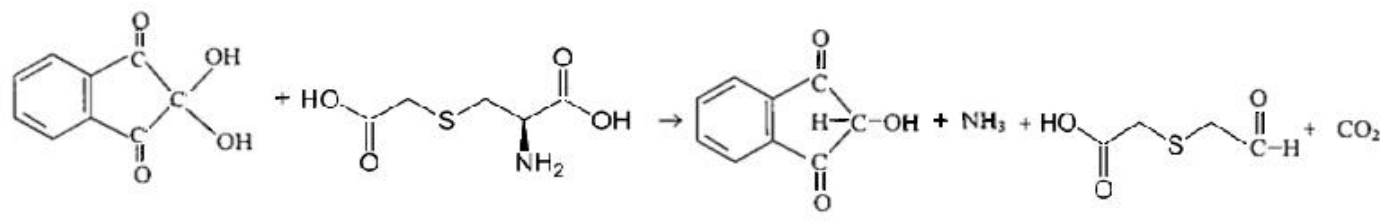<smiles>[Y10]Nc1ccccc1</smiles>

Scheme 3: The possible reaction mechanism of $[\mathrm{CS}]:[\mathrm{NN}]$ complex formation. 


\section{Calibration curve}

The calibration curve of carbocisteine in pure form through complexation with ninhydrin showed excellent linearity over concentration range of $1.00-100.00 \mu \mathrm{mol} . \mathrm{L}^{-1}(0.1792-17.919$ g.mL ${ }^{-1}$ ) for the solvents (methanol, ethanol, isopropanol and acetonitrile with water ratio 1:1) in presence of $2.5 \times 10^{-2}$ mol. $\mathrm{L}^{-1}$ of ninhydrin with good correlation coefficient in studied solvents. Regression equation at $\lambda_{\max }$ was as the follows: $\mathrm{y}_{1}=0.0749 \mathrm{x}+0.0007\left(\mathrm{R}^{2}=0.9999\right)$, $\mathrm{y}_{2}=0.0733 \mathrm{x}+0.0002\left(\mathrm{R}^{2}=0.9997\right)$, $\mathrm{y}_{3}=0.0635 \mathrm{x}+0.0025\left(\mathrm{R}^{2}=0.9996\right)$ and $\mathrm{y}_{4}=0.0491 \mathrm{x}+0.0002\left(\mathrm{R}^{2}=0.9994\right)$, in methanol, ethanol, isopropanol and acetonitrile, respectively. Figures 7-10 showed the spectra of [CS]:[NN] complex in presence of $2.5 \times 10^{-2} \mathrm{M}$ of NN. The spectra characteristics of the method such as the molar absorptivity ( $\varepsilon$, Beer's law, regression equation at $\lambda_{\max }(y=a . x+b)$; where $\mathrm{y}=$ absorbance, $\mathrm{a}=$ slope, $\mathrm{x}=$ concentration of CS by g.mL ${ }^{-1}, b=$ intercept, the correlation coefficient, limit of detection (LOD) and limit of quantification (LOQ) and the optimum conditions for spectrophotometric determination of CS through formation complex using $\mathrm{NN}$ in mentioned solvents is summarized in Table 1.

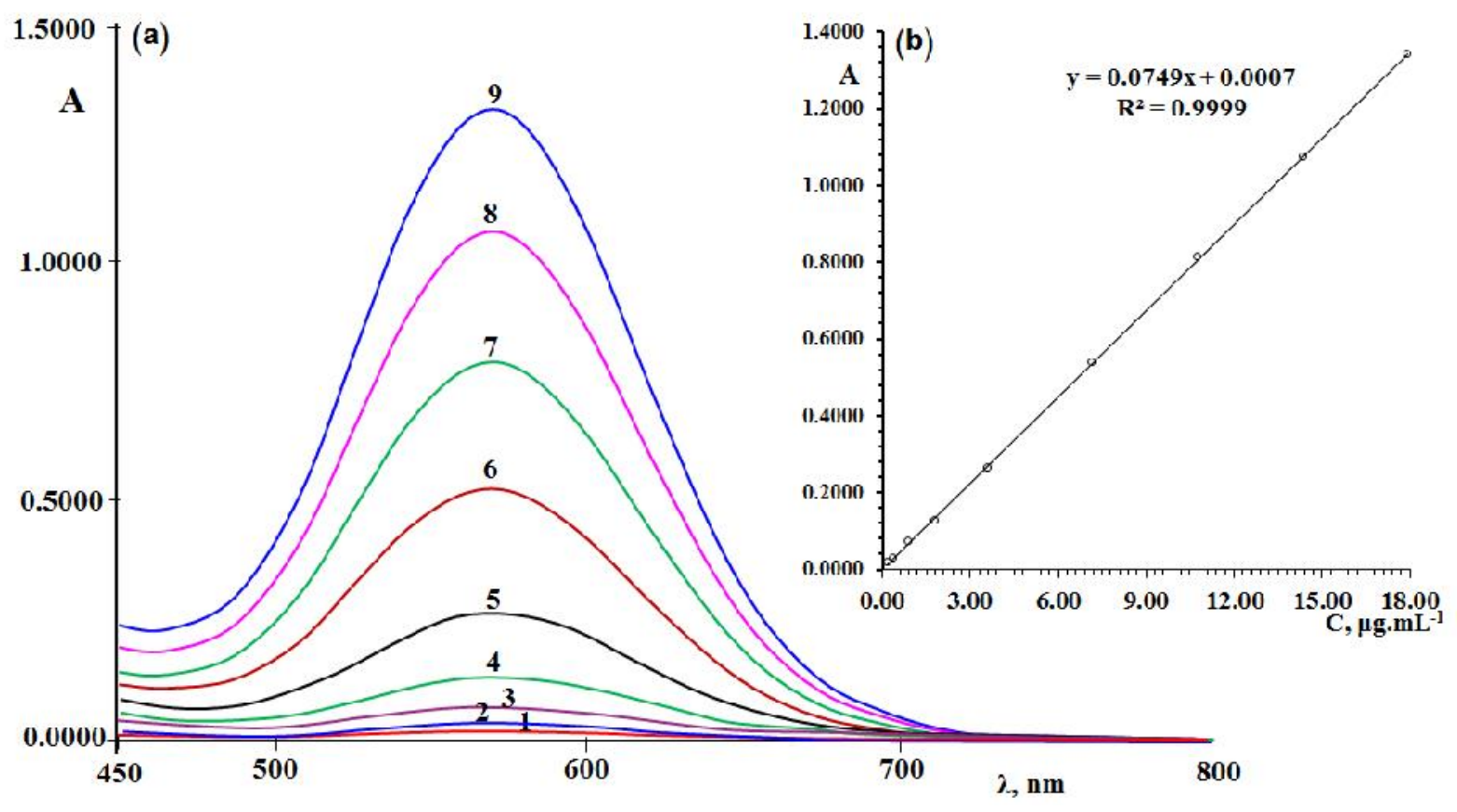

Fig.7: (a) Spectra and calibration curve of $[\mathrm{CS}]:[\mathrm{NN}]$ complex in presence of $2.5 \times 10^{-2} \mathrm{M}$ of $\mathrm{NN}$; where concentration of CS as the follows: 1- 0.1792, 2- 0.3584, 3- 0.8960, 4- 1.7919, 5- 3.5838, 6- 7.1676, 7- $10.7514,8-14.3352$, 9- $17.9190 \mathrm{~g} \cdot \mathrm{mL}^{-1}\left(\ell=1.0 \mathrm{~cm}\right.$, blank is $2.5 \times 10^{-2} \mathrm{M}$ of $\mathrm{NN}$ in methanol).

(b) Calibration curve of CS in pure form through complexation with $\mathrm{NN}$ in presence of $2.5 \times 10^{-2} \mathrm{~mol} . \mathrm{L}^{-1}$ of $\mathrm{NN}$ in methanol. 


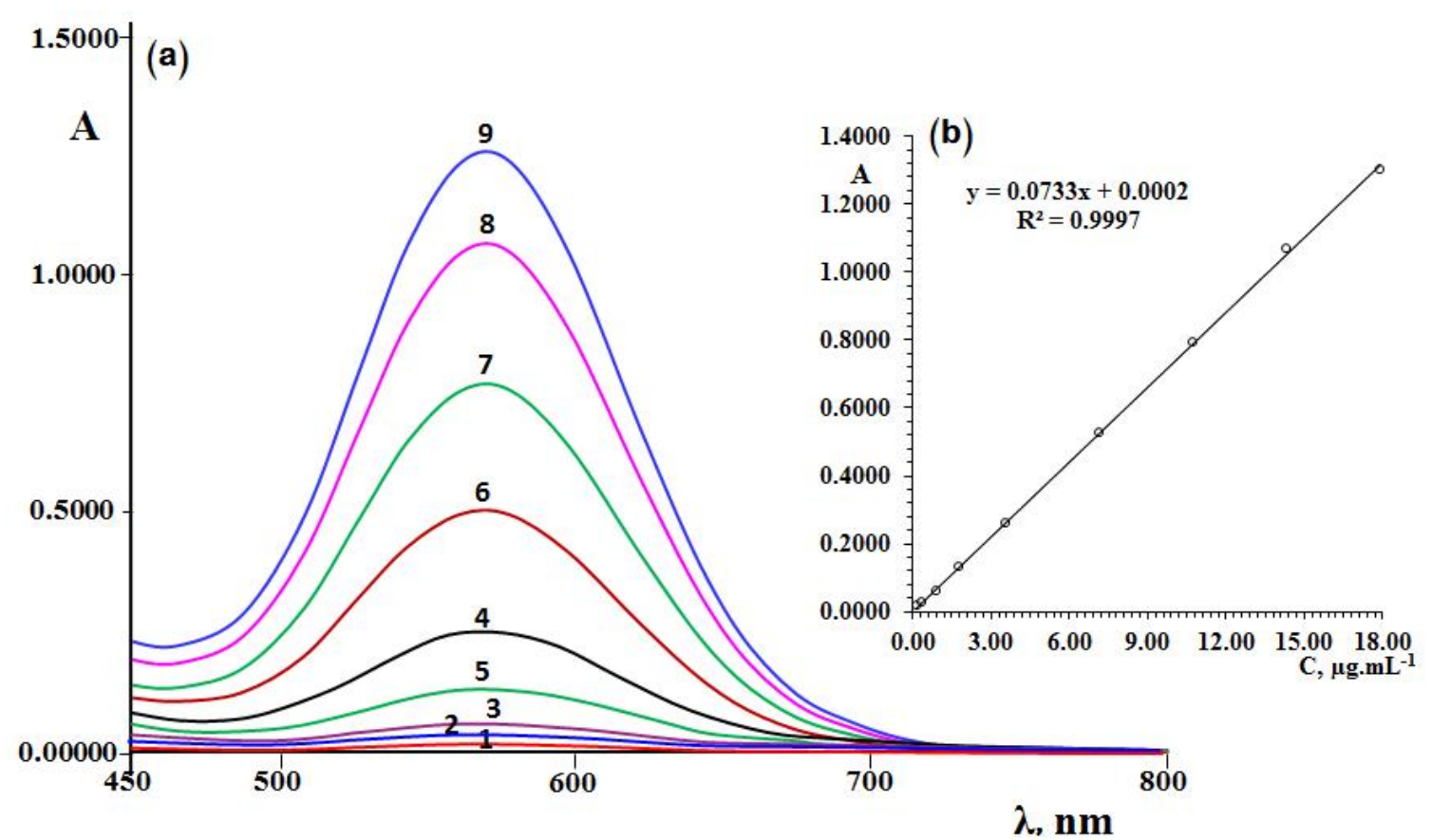

Fig. 8: (a) Spectra and calibration curve of $[\mathrm{CS}]:[\mathrm{NN}]$ complex in presence of $2.5 \times 10^{-2} \mathrm{M}$ of $\mathrm{NN}$; where concentration of CS as the follows: 1- 0.1792, 2- 0.3584, 3- 0.8960, 4- 1.7919, 5- 3.5838, 6- 7.1676, 7- $10.7514,8-14.3352$, 9- 17.9190 g.mL ${ }^{-1}\left(\ell=1.0 \mathrm{~cm}\right.$, blank is $2.5 \times 10^{-2} \mathrm{M}$ of NN in ethanol).

(b) Calibration curve of CS in pure form through complexation with $\mathrm{NN}$ in presence of $2.5 \times 10^{-2} \mathrm{~mol}^{-\mathrm{L}^{-1}}$ of $\mathrm{NN}$ in ethanol.

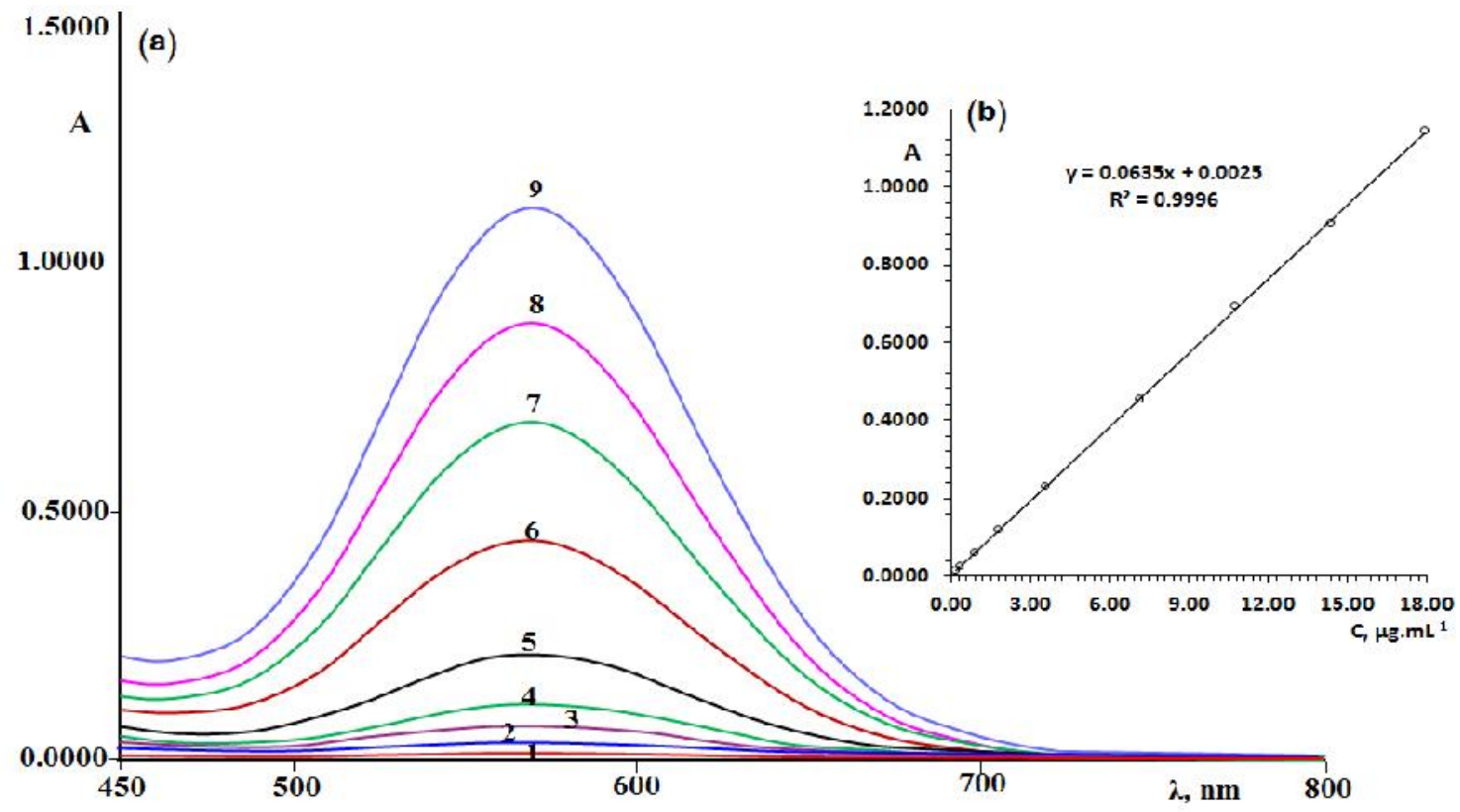

Fig. 9: (a) Spectra and calibration curve of [CS]:[NN] complex in presence of $2.5 \times 10^{-2} \mathrm{M}$ of $\mathrm{NN}$; where concentration of CS as the follows: 1- 0.1792, 2- 0.3584, 3- 0.8960, 4- 1.7919, 5- 3.5838, 6- 7.1676, 7- $10.7514,8-14.3352$, 9- 17.9190 g. $\mathrm{mL}^{-1}\left(\ell=1.0 \mathrm{~cm}\right.$, blank is $2.5 \times 10^{-2} \mathrm{M}$ of $\mathrm{NN}$ in isopropanol).

(b) Calibration curve of CS in pure form through complexation with $\mathrm{NN}$ in presence of $2.5 \times 10^{-2} \mathrm{~mol} . \mathrm{L}^{-1}$ of $\mathrm{NN}$ in isopropanol. 


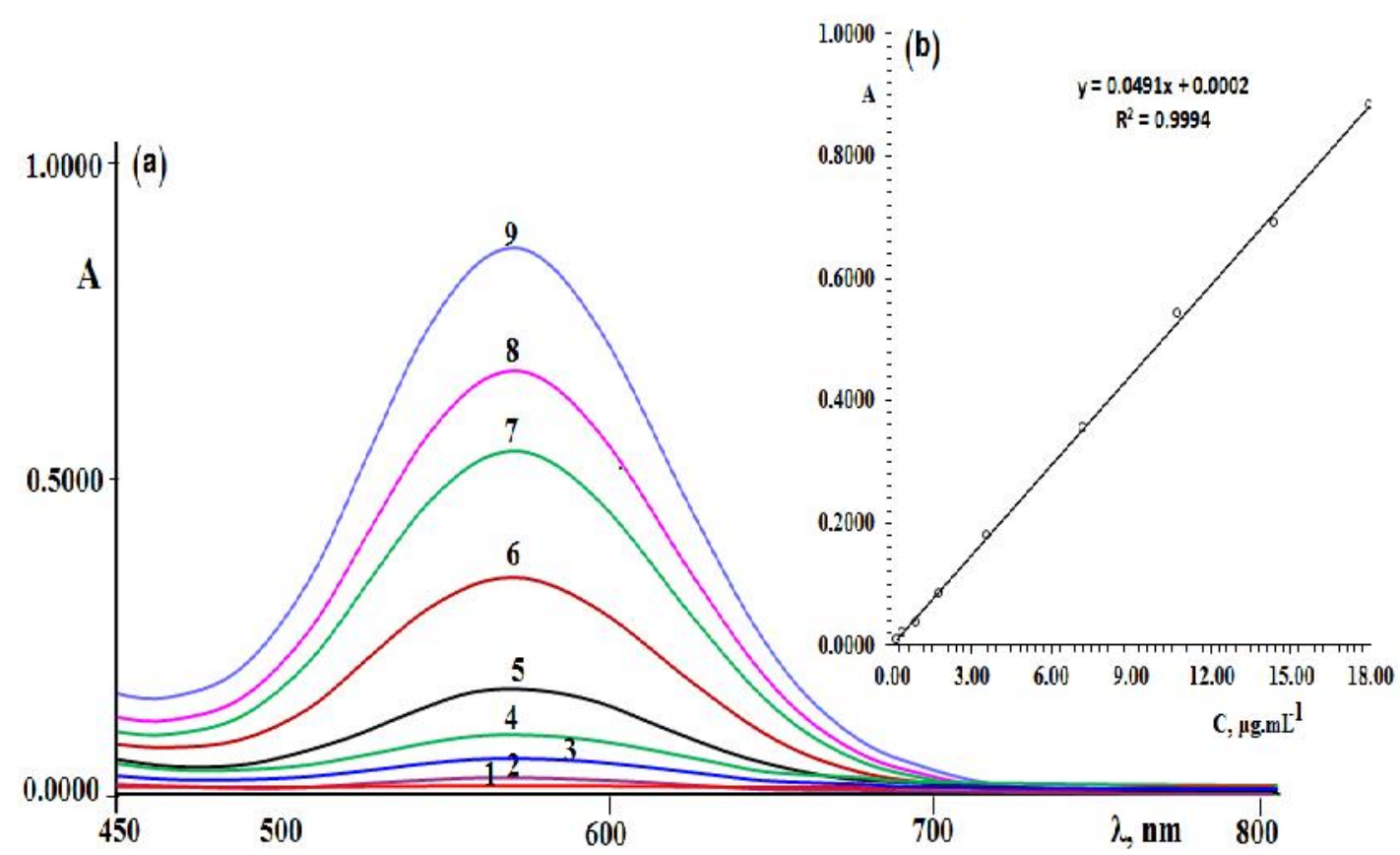

Fig. 10: (a) Spectra and calibration curve of $[\mathrm{CS}]:[\mathrm{NN}]$ complex in presence of $2.5 \times 10^{-2} \mathrm{M}$ of $\mathrm{NN}$; where concentration of CS as the follows: 1- 0.1792, 2- 0.3584, 3- 0.8960, 4- 1.7919, 5- 3.5838, 6- 7.1676, 7- $10.7514,8-14.3352$, 9- $17.9190 \mathrm{~g} \cdot \mathrm{mL}^{-1}\left(\ell=1.0 \mathrm{~cm}\right.$, blank is $2.5 \times 10^{-2} \mathrm{M}$ of NN in acetonitrile).

(b) Calibration curve of $\mathrm{CS}$ in pure form through complexation with $\mathrm{NN}$ in presence of $2.5 \times 10^{-2} \mathrm{~mol} . \mathrm{L}^{-1}$ of $\mathrm{NN}$ in acetonitrile.

Table 1. The parameters established for spectrophotometric determination of CS by formation complex with NN in studied solvent-water (1:1).

\begin{tabular}{|c|c|c|c|c|}
\hline \multirow{2}{*}{ Parameters } & \multicolumn{4}{|c|}{ Operating values } \\
\hline & Methanol & Ethanol & Isopropanol & Acetonitrile \\
\hline$\lambda_{\max }$ of $\mathrm{CS}: \mathrm{NN}$ complex, $\mathrm{nm}$ & 570 & 572 & 569 & 568 \\
\hline Beer's Law Limit by mol.L $\mathrm{L}^{-1}$ & \multicolumn{4}{|c|}{$1.00-100.00$} \\
\hline Beer's Law Limit by g.mL ${ }^{-1}$ & \multicolumn{4}{|c|}{$0.1792-17.9190$} \\
\hline$\varepsilon$ of complex $\left(\mathrm{L}^{\mathrm{mol}}{ }^{-1} . \mathrm{cm}^{-1}\right)$ & 13425 & 13180 & 11387 & 8827 \\
\hline$Y=a . x+b$ for complex at $\lambda_{\max }$ & $y=0.0749 x+0.0007$ & $y=0.0733 x+0.0002$ & $y=0.0635 x+0.0025$ & $y=0.0491 x+0.0002$ \\
\hline Slope & 0.0749 & 0.0733 & 0.0635 & 0.0491 \\
\hline Intercept & 0.0007 & 0.0002 & 0.0025 & 0.0002 \\
\hline Correlation coefficient $\left(R^{2}\right)$ & 0.9999 & 0.9997 & 0.9996 & 0.9994 \\
\hline $\mathrm{C}_{\mathrm{NN}}: \mathrm{C}_{\mathrm{CS}}, \mathrm{M}$ & \multicolumn{4}{|c|}{$\geq 250$} \\
\hline Stability & \multicolumn{4}{|c|}{24 hour } \\
\hline Temperature of solution & \multicolumn{4}{|c|}{$90 \pm 2^{\circ} \mathrm{C}$} \\
\hline
\end{tabular}
$\mathrm{n}=5, \mathrm{t}=2.776$. 


\section{Analytical results}

Spectrophotometric determination of carbocisteine through complexation with ninhydrin in solvents (methanol, ethanol, isopropanol and acetonitrile) within optimal conditions using calibration curve was applied. The results, summarized in Table 2, showed that the determined concentrations of CS were rectilinear over the range of 1.00 to $100.00 \mu \mathrm{M}$ (0.1792 to 17.919 g.mL $\left.{ }^{-1}\right)$ with relative standard deviation (RSD) not more than $3.2 \%$ for the concentrations of CS $\left(0.1792\right.$ g. $\left.\mathrm{mL}^{-1}\right)$ in methanol as example. The results obtained from the developed method have been compared with the official RP-HPLC method [13]. The compatibility between them was good.

Table 2: Spectrophotometric determination of CS through formation complex with NN within optimal conditions using calibration curve in studied solvent.

\begin{tabular}{|c|c|c|c|c|}
\hline $\begin{array}{c}\mathrm{X}_{\mathrm{i}} \\
\mu \mathrm{g.mL} \mathbf{L}^{-1} \\
\text { (Taken) }\end{array}$ & Solvents & $\begin{array}{c}* \bar{X} \pm \text { SD } \\
\mu \text { g.mL } \\
-1 \text { (Found) }\end{array}$ & $\overline{x \pm} \frac{t . S D}{\sqrt{n}}, \boldsymbol{\mu g} \cdot \mathbf{m L}^{-1}$ & RSD\% \\
\hline \multirow{4}{*}{0.1792} & Methanol & $0.1822 \pm 0.0058$ & $0.1822 \pm 0.0072$ & 3.2 \\
\hline & Ethanol & $0.1853 \pm 0.0061$ & $0.1923 \pm 0.0076$ & 3.3 \\
\hline & Isopropanol & $0.1811 \pm 0.0063$ & $0.1811 \pm 0.0078$ & 3.5 \\
\hline & Acetonitrile & $0.1772 \pm 0.0073$ & $0.1772 \pm 0.0091$ & 4.1 \\
\hline \multirow{4}{*}{0.3584} & Methanol & $0.3645 \pm 0.0109$ & $0.3645 \pm 0.0135$ & 3.0 \\
\hline & Ethanol & $0.3386 \pm 0.0108$ & $0.3386 \pm 0.0134$ & 3.2 \\
\hline & Isopropanol & $0.3684 \pm 0.0125$ & $0.3684 \pm 0.0156$ & 3.4 \\
\hline & Acetonitrile & $0.3796 \pm 0.0144$ & $0.3796 \pm 0.0179$ & 3.8 \\
\hline \multirow{4}{*}{0.8960} & Methanol & $0.9115 \pm 0.0273$ & $0.9115 \pm 0.0339$ & 3.0 \\
\hline & Ethanol & $0.8758 \pm 0.0271$ & $0.8758 \pm 0.0336$ & 3.1 \\
\hline & Isopropanol & $0.9055 \pm 0.0299$ & $0.9055 \pm 0.0371$ & 3.3 \\
\hline & Acetonitrile & $0.8438 \pm 0.0312$ & $0.8438 \pm 0.0387$ & 3.7 \\
\hline \multirow{4}{*}{1.7919} & Methanol & $1.7872 \pm 0.0518$ & $1.7872 \pm 0.0643$ & 2.9 \\
\hline & Ethanol & $.7981 \pm 0.05571$ & $.7981 \pm 0.06921$ & 3.1 \\
\hline & Isopropanol & $.8189 \pm 0.05821$ & $.8189 \pm 0.07231$ & 3.2 \\
\hline & Acetonitrile & $1.7426 \pm 0.0627$ & $1.7426 \pm 0.0778$ & 3.6 \\
\hline \multirow{4}{*}{3.5838} & Methanol & $3.5587 \pm 0.0996$ & $3.5587 \pm 0.1237$ & 2.8 \\
\hline & Ethanol & $3.5643 \pm 0.1070$ & $3.5643 \pm 0.1328$ & 3.0 \\
\hline & Isopropanol & $.5984 \pm 0.11163$ & $.5984 \pm 0.13863$ & 3.1 \\
\hline & Acetonitrile & $3.6112 \pm 0.1264$ & $3.6112 \pm 0.1569$ & 3.5 \\
\hline \multirow{4}{*}{7.1676} & Methanol & $7.1623 \pm 0.1934$ & $7.1623 \pm 0.2401$ & 2.7 \\
\hline & Ethanol & $7.1863 \pm 0.2084$ & $7.1863 \pm 0.2587$ & 2.9 \\
\hline & Isopropanol & $7.1389 \pm 0.2142$ & $7.1389 \pm 0.2659$ & 3.0 \\
\hline & Acetonitrile & $7.2261 \pm 0.2457$ & $7.2261 \pm 0.3050$ & 3.4 \\
\hline
\end{tabular}


Int. J. Curr. Res. Chem. Pharm. Sci. (2021). 8(5): 27-41

\begin{tabular}{|c|c|c|c|c|}
\hline \multirow{3}{*}{10.7514} & Methanol & $10.8718 \pm 0.2827$ & $10.8718 \pm 0.3510$ & $\mathbf{2 . 6}$ \\
\cline { 2 - 5 } & Ethanol & $10.8158 \pm 0.3028$ & $10.8158 \pm 0.3759$ & 2.8 \\
\cline { 2 - 5 } & Isopropanol & $10.8740 \pm 0.3153$ & $10.8740 \pm 0.3914$ & 2.9 \\
\cline { 2 - 5 } & Acetonitrile & $11.0153 \pm 0.3415$ & $11.0153 \pm 0.4240$ & 3.1 \\
\hline \multirow{3}{*}{14.3352} & Methanol & $14.3325 \pm 0.3583$ & $14.3325 \pm 0.4448$ & 2.5 \\
\cline { 2 - 5 } & Ethanol & $14.5218 \pm 0.3776$ & $14.5218 \pm 0.4688$ & 2.6 \\
\cline { 2 - 5 } & Isopropanol & $14.2598 \pm 0.3993$ & $14.2598 \pm 0.4957$ & 2.8 \\
\cline { 2 - 5 } & Acetonitrile & $14.1326 \pm 0.4240$ & $14.1326 \pm 0.5264$ & 3.0 \\
\hline & Methanol & $17.8866 \pm 0.4293$ & $17.8866 \pm 0.5330$ & 2.4 \\
\cline { 2 - 5 } & Ethanol & $17.5756 \pm 0.4570$ & $17.5756 \pm 0.5674$ & 2.6 \\
\cline { 2 - 5 } & Isopropanol & $17.9610 \pm 0.4849$ & $17.9610 \pm 0.6020$ & 2.7 \\
\cline { 2 - 5 } & Acetonitrile & $17.9796 \pm 0.5394$ & $17.9796 \pm 0.6700$ & 3.0 \\
\hline
\end{tabular}

$\mathrm{n}=5, \mathrm{t}=2.776$.

Table 3: Determination of carbocisteine in some Syrian pharmaceutical preparations using spectrophotometric method through formation complex with $2.5 \times 10^{-2} \mathrm{M}$ of $\mathrm{NN}$ within optimal conditions using calibration curve in methanol.

\begin{tabular}{|c|c|c|c|c|c|c|}
\hline Dosage form & $\begin{array}{l}\text { Label } \\
\text { Claim } \\
\text { of CS, } \\
\text { mg/cap }\end{array}$ & $\begin{array}{l}* \text { Mean } \pm \text { SD } \\
\text { CS, mg/cap }\end{array}$ & RSD\% & $\begin{array}{c}\text { Assay } \\
\%\end{array}$ & $\begin{array}{c}* \text { Mean } \pm \text { SD } \\
\text { CS, mg/tab } \\
\text { by RP-HPLC } \\
{[13]}\end{array}$ & $\begin{array}{c}* \begin{array}{c}\text { Assay \%, } \\
\text { by } \\
\text { RP-HPLC }[13]\end{array}\end{array}$ \\
\hline $\begin{array}{c}\text { Mucolar capsule, } \\
\text { ELSAAD } \\
\text { PHARMACEUTICAL }\end{array}$ & 375 & $385 \pm 10.01$ & 2.6 & 102.7 & $383 \pm 10.25$ & 102.1 \\
\hline $\begin{array}{c}\text { Mucoxil capsule, } \\
\text { Al-SHAHBA } \\
\text { PHARMACEUTICAL }\end{array}$ & 375 & $380 \pm 10.26$ & 2.7 & 101.3 & $381 \pm 10.52$ & 101.6 \\
\hline $\begin{array}{c}\text { Carbocisteie capsule, } \\
\text { Al-YOUSEF } \\
\text { PHARMACEUTICAL }\end{array}$ & 375 & $373 \pm 10.07$ & 2.7 & 99.5 & $374 \pm 11.0$ & 99.7 \\
\hline
\end{tabular}

$$
* \mathrm{n}=5 \text {. }
$$

\section{Method validation}

The developed method for simultaneous estimation of carbocisteine has been validated in accordance with the International Conference on Harmonization guidelines (ICH) [17].

\section{Linearity}

Several aliquots of standard stock solution of carbocisteine were taken in different $5 \mathrm{~mL}$ volumetric flask and diluted up to the mark with

(C) 2021, IJCRCPS. All Rights Reserved studied solvents such that their final concentrations were $0.1792-17.919$ g.mL $\mathrm{mL}^{-1}$ of CS. Absorbance was plotted against the corresponding concentrations to obtain the calibration graph, see Figures 7-10 and Table 2. Linearity equations obtained at $\lambda_{\max }$ suitable for used solvent were applied, see Table 1 .

\section{Precision and Accuracy}

The precision and accuracy of proposed method was checked by recovery study by addition of standard drug solution to pre-analyzed sample 
solution at three different concentration levels (80\%, 100\% and 120\%) within the range of linearity for carbocisteine. The basic concentration level of sample solution selected for spiking of the carbocisteine standard solution was 7.1676 g.mL ${ }^{-1}$. The proposed method was validated statistically and through recovery studies, and was successfully applied for the determination of carbocisteine in pure and dosage forms with percent recoveries ranged from $99.2 \%$ to $101.3 \%$, see Table 4 (in methanol as example).

Table 4: Results of recovery studies (in methanol as example).

\begin{tabular}{|c|c|}
\hline Level & \% Recovery \\
\hline $80 \%$ & 99.2 \\
\hline $100 \%$ & 101.3 \\
\hline $120 \%$ & 101.2 \\
\hline
\end{tabular}

\section{Repeatability}

The repeatability was evaluated by performing 10 repeat measurements for 10.7514 g. $\mathrm{mL}^{-1}$ of carbocisteine using the studied spectrophotometric method under the optimum conditions. The found amount of carbocisteine $\left(\bar{x} \pm\right.$ SD) $\quad 10.8716 \pm 0.2718 \quad$ g.mL $L^{-1}$ (in dichloromethane as example). The percentage recovery was found to be $101.1 \pm 2.5$ with RSD of 0.025 . These values indicate that the proposed method has high repeatability for carbocisteine analysis.

\section{Sensitivity (LOD and LOQ)}

The sensitivity of the method was evaluated by determining the LOD and LOQ. The values of
LOD and LOQ for carbocisteine are 0.019 and 0.058 g.mL $\mathrm{mL}^{-1}$ (in methanol as example).

\section{Robustness}

The robustness of the method adopted is demonstrated by the constancy of the absorbance with the deliberated minor change in the experimental parameters such as the change in the concentration of excipients, temperature $\left(90 \pm 2^{\circ} \mathrm{C}\right)$, stability $(23-25 \mathrm{~h})$ and reaction time $(15 \pm 1 \mathrm{~min})$, see Table 5 which indicates the robustness of the proposed method. The absorbance was measured and assay was calculated for five times (in methanol as example).

Table 5: Robustness of the proposed spectrophotometric method (in methanol as example).

\begin{tabular}{|c|c|c|}
\hline \multirow{2}{*}{$\begin{array}{c}\text { Experimental parameter } \\
\text { variation }\end{array}$} & \multicolumn{2}{|c|}{ Average recovery (\%) } \\
\cline { 2 - 3 } & $0.3584 \mathrm{~g} \cdot \mathrm{mL}^{-1}$ & $1.7919 \mathrm{~g} \cdot \mathrm{mL}^{-1}$ \\
\cline { 2 - 3 } & 99.6 & 99.8 \\
\hline Temperature & 100.6 \\
$88^{\circ} \mathrm{C}$ & 100.5 & 100.0 \\
$92^{\circ} \mathrm{C}$ & 99.9 & 100.5 \\
\hline Stability & 100.2 & 99.4 \\
23 hour & 99.2 & 100.8 \\
25 hour & 100.6 & \\
\hline Reaction time & & \\
14.0 min & & \\
16.0 min & &
\end{tabular}




\section{Selectivity}

Several other components were examined under the conditions that had been optimized for carbocisteine determination. The results show that guaifenesin and oxomemazine did not interfere when it presents at same amount with carbocisteine.

\section{Specificity}

The specificity of the method was ascertained by analyzing standard CS in presence of excipients. These findings prove that the suggested methods are specific for determination of the investigated drugs without interference from the co-formulated adjuvants.

\section{Conclusion}

Effect of solvents (methanol, ethanol, isopropanol and acetonitrile with water ratio 1:1) on direct spectrophotometric determination of carbocisteine (CS) in pure form and pharmaceutical formulations using ninhydrin (NN) was studied. The method is based on reaction between CS and $\mathrm{NN}$ and formation complex. The peak of these complex's occurs at wavelengths from 568-572 $\mathrm{nm}$. The absorbance's were proportional to the concentration of CS at range 1.00 to $100.00 \mu \mathrm{M}$ $\left(0.1792\right.$ to 17.919 g.mL $\left.\mathrm{mL}^{-1}\right)$ in present $2.5 \times 10^{-2} \mathrm{M}$ of NN. The method was validated for linearity, precision and accuracy, repeatability and robustness. The method was successfully applied for determination of CS in pure and pharmaceutical formulations samples with relative standard deviations did not exceed $3.2 \%$ for the concentrations of CS $\left(0.1792\right.$ g.mL $\left.{ }^{-1}\right)$ in methanol as example.

\section{References}

1. Neil J.O., 1995 - "The Merck Index, Merck Research Laboratories". 12th Ed., Martindale, Merck.

2. Budavari S, 2011-"The Merck Index" 13th Ed. Merck \& Co. Inc. 856.
3. British Pharmacopoeia, 2009- Her Majesty's Stationary Office, London. Volume I, II, and III,

4. Walash M.I., El-Brashy A.M., Metwally M.E., Abdelal A.A., 2004- Fluorimetric determination of carbocisteine and ethionamide in drug formulation, Acta Chim. Slov, 51: 283-291.

5. Ayad M.M., Abdellatef H.E., Hosny M.M., Sharaf Y.A., 2013- Application of 4-chloro-7-nitrobenzofurazan for the analysis of propafenone and diltiazem hydrochlorides using kinetic spectrophotometric and spectrofluorimetric methods, European Journal of Chemistry, 4(1): 35-43.

6. Walash M.I., El-Brashy A.M., Metwally M. E., Abdelal A.A., 2004- Spectrophotometric determination of penicillamine and carbocisteine based on formation of metal complexes, IL FARMACO, 59: 493-503.

7. Rele R.V., 2014 - Simultaneous spectrophotometric estimation of amoxicillin and carbocisteine by second order derivative spectroscopy method in combined dosage form, Int. J. Chem. Sci, 12(4):1587-1595.

8. Rele R.V., Patil S.S., 2013- Ultra-violet spectrophotometric method for validation of carbocisteine from bulk drug and pharmaceutical formulation, Int $\mathrm{J}$ Pharm Bio Sci, 4(2): 847 - 851.

9. Li S.Y., Guo Q.L., Yuan W., Hou Y.C., Du L.M., 2010- Spectrophotometric study of the charge transfer complexation of some amino acid derivative drugs as electron donors with 7, 7, 8, 8 - tetracyanoquinodimethane, Bull. Chem. Soc. Ethiop, 24(1): 21-30.

10. Wu F.Y., Liao W.S., Wu Y.M., Wan X.F., 2008-Spectroscopic determination of cysteine with alizarin red $\mathrm{S}$ and copper, Spectroscopy Letters, 41:393-398.

11. Taha E.A., Hassan N.Y., Abdel Aal F., ElSayed Abdel Fattah L., 2008- Kinetic spectrophotometric determination of acetylcysteine and carbocisteine in bulk powder and in drug formulations, Science Asia, 34:107-113. 
12. Walash M.I., Metwally M.E., El-Brashy A.M., Abdelal A.A., 2003- Kinetic spectrophotometric determination of some sulfur containing compounds in pharmaceutical preparations and human serum, Il Farmaco, 58 : 1325-1332.

13. Rele R. V, Patil S. P. 2010-Reversed Phase High Pressure Liquid Chromatography Technique for Determination of Carbocisteine from Pharmaceutical Formulation, J.Chem.Parm.Res., 2(4), 24-30.

14. Rele R.V, Rane D.G., 2017- Validation of Carbocisteine by Reversed Phase High Performance Liquid Chromatography Method from Active Pharmaceutical Dosage Form, International Journal of ChemTech Research, 10(5):583-589.
15. Chauhan K., Mujawar A., Quazi I., 2016HPTLC method development and validation for densitometric analysis of carbocisteine in drug formulation, International Journal of Applied Pharmaceutics, 8(4):22-25.

16. Siddiqui F.A., Sher N., Naz A., Hasan N., Shah S.N., Shehzad M., 2019- Kinetic Approach to Determine 3-Amino Methyl Hexanoic Acid in Pharmaceutical Formulations, Afr. J. Chem.,72:189-194.

17. ICH: Proceedings of the International Conference on Harmonization of Technical Requirement of Registration of Pharmaceuticals for Human Use (ICH Harmonized Tripartite Guidelines), 2005.

\begin{tabular}{|c|c|}
\hline \multicolumn{2}{|c|}{ Access this Article in Online } \\
\hline \multirow{2}{*}{ 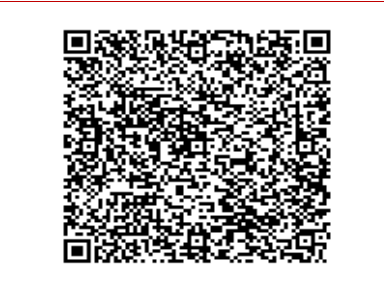 } & $\begin{array}{l}\text { Website: } \\
\text { www.ijcrcps.com }\end{array}$ \\
\hline & $\begin{array}{l}\text { Subject: } \\
\text { Chemistry }\end{array}$ \\
\hline Quick Response Code & \\
\hline & 2021.08 \\
\hline
\end{tabular}

How to cite this article:

Abdul Aziz Ramadan, Hasna Mandil, Ali Marei. (2021). Effect of Solvents on Spectrophotometric Analysis of Carbocisteine by Forming Complex with Ninhydrin . Int. J. Curr. Res. Chem. Pharm. Sci. 8(5): 27-41. DOI: http://dx.doi.org/10.22192/ijcrcps.2021.08.05.004 